\title{
The heat-shock response of Listeria monocytogenes comprises genes involved in heat shock, cell division, cell wall synthesis, and the SOS response
}

\section{Correspondence \\ Stijn van der Veen \\ Stijn.vanderVeen@wur.nl}

Received 5 February 2007

Revised 5 June 2007

Accepted 15 June 2007
Stijn van der Veen, ${ }^{1,2,3} \dagger$ Torsten Hain, ${ }^{4} \dagger$ Jeroen A. Wouters, ${ }^{2}$ Hamid Hossain, ${ }^{4}$ Willem M. de Vos, ${ }^{1}$ Tjakko Abee, ${ }^{1,3}$ Trinad Chakraborty ${ }^{4}$ and Marjon H. J. Wells-Bennik ${ }^{1,2}$

\author{
${ }^{1}$ Wageningen Centre for Food Sciences (WCFS), Diedenweg 20, 6703 GW Wageningen, \\ The Netherlands \\ ${ }^{2}$ Division of Health and Safety, NIZO Food Research, Kernhemseweg 2, 6718 ZB Ede, \\ The Netherlands \\ ${ }^{3}$ Laboratory of Food Microbiology, Wageningen University and Research Centre, Bomenweg 2, \\ 6703 HD Wageningen, The Netherlands \\ ${ }^{4}$ Institute of Medical Microbiology, Justus-Liebig University, Frankfurter Strasse 107, 35392 \\ Giessen, Germany
}

\begin{abstract}
The food-borne pathogen Listeria monocytogenes has the ability to survive extreme environmental conditions due to an extensive interacting network of stress responses. It is able to grow and survive at relatively high temperatures in comparison with other non-sporulating food-borne pathogens. To investigate the heat-shock response of $L$. monocytogenes, whole-genome expression profiles of cells that were grown at $37{ }^{\circ} \mathrm{C}$ and exposed to $48{ }^{\circ} \mathrm{C}$ were examined using DNA microarrays. Transcription levels were measured over a $40 \mathrm{~min}$ period after exposure of the culture to $48{ }^{\circ} \mathrm{C}$ and compared with those of unexposed cultures at $37{ }^{\circ} \mathrm{C}$. After $3 \mathrm{~min}, 25 \%$ of all genes were differentially expressed, while after 40 min only $2 \%$ of all genes showed differential expression, indicative of the transient nature of the heat-shock response. The global transcriptional response was validated by analysing the expression of a set of 13 genes by quantitative PCR. Genes previously identified as part of the class I and class III heat-shock response and the class II stress response showed induction at one or more of the time points investigated. This is believed to be the first study to report that several heat-shock-induced genes are part of the SOS response in L. monocytogenes. Furthermore, numerous differentially expressed genes that have roles in the cell division machinery or cell wall synthesis were down-regulated. This expression pattern is in line with the observation that heat shock results in cell elongation and prevention of cell division.
\end{abstract}

†These authors contributed equally to this work.

Abbreviation: Q-PCR, quantitative PCR.

Supplementary tables of the sequences of the Q-PCR primers and the genes that show differential expression at different time points after exposure to a temperature of $48{ }^{\circ} \mathrm{C}$ are available with the online version of this paper.

The microarray platform and microarray data discussed in this publication have been deposited in ArrayExpress (http://www.ebi.ac. uk/arrayexpress) under accession numbers A-MEXP-752 and E-MEXP-1118, respectively.

\section{INTRODUCTION}

The food-borne pathogen Listeria monocytogenes is a Gram-positive facultative anaerobic rod and the causative agent of listeriosis. Due to the severity of the disease and the fact that its incidence is increasing in numerous European countries, L. monocytogenes is of great public health concern (Doorduyn et al., 2006; Health Protection Agency, 2005; Koch \& Stark, 2006). This bacterium shows relatively high resistance to environmental insults compared with many other non-spore-forming food-borne pathogens. It is able to grow at a wide $\mathrm{pH}$ range (from 
$\mathrm{pH} 5$ to $\mathrm{pH}$ 9), at high salt concentrations (up to $12 \%$ ), and at a wide range of temperatures $\left(-0.4\right.$ to $\left.44{ }^{\circ} \mathrm{C}\right)$ (Kallipolitis \& Ingmer, 2001; Karatzas et al., 2005). The ability of $L$. monocytogenes to proliferate under adverse conditions and survive environmental insults is mediated by various mechanisms that allow for rapid responses and adaptations to changing environments. Due to consumers' demands for less heavily preserved foods and more convenience foods, processing conditions in the food industry are becoming milder. L. monocytogenes is able to adapt to such milder conditions, making it of major concern to the food industry.

Variation in temperature is a stress that is commonly encountered in nature and during the processing of foods. DNA microarrays provide an excellent tool to study the expression profiles of a complete genome during exposure to heat stress. Previous studies involving transcriptional analysis of the heat-shock response in various bacteria have shown induction of several protection mechanisms, including general protection mechanisms and specific heat-shock responses. The heat-shock response is a common phenomenon among bacteria that enables them to survive a wide variety of stresses, in particular heat stress. Most heat-stress-induced genes encode molecular chaperones or proteases that can either protect other proteins/enzymes against misfolding and damage or mediate degradation when this fails. Maintenance of protein quality is important for normal growth of cells and is essential under stress conditions. In L. monocytogenes, two specific heat-shock-response mechanisms and a general stress-response mechanism can be distinguished, namely, the class I and class III heat-shock response, and the class II stress response (Benson \& Haldenwang, 1993; Kruger \& Hecker, 1998; Schulz \& Schumann, 1996). Class I heat-shock genes are controlled by the HrcA repressor, which binds to the CIRCE operator sequence (TTAGCACTC-N ${ }_{9}$-GAGTGCTAA) preceding this class of genes. Class I heat-shock genes include dnaK, dnaJ, groES and groEL, encoding chaperones. Class III heat-shock genes encode chaperones and ATP-dependent Clp proteases, which degrade damaged or misfolded proteins. This class is regulated by the CtsR repressor, which binds specifically to a heptanucleotide repeat in the promoter region (A/GGTCAAANANA/GGTCAAA). The class II stress genes encode general stress proteins, of which the expression is regulated by the alternative sigma factor SigB. This sigma factor recognizes alternative -35 and -10 sequences (GTTT-N ${ }_{13-17}$-GGGWAT) in the promoter region of the class II stress genes (Kazmierczak et al., 2003).

The complete heat-shock regulon of L. monocytogenes that acts in response to a temperature increase has, apparently, not been investigated before, even though heating is an important preservation strategy for the food industry during minimal processing. The aim of this study was to determine the global transcriptional response of $L$. monocytogenes to heat stress. Our data show that exposure to elevated temperatures triggers the classical heat-shock genes, and, in addition, a transient effect on expression of genes involved in the cell replication machinery was observed. Another novel finding is that heat shock triggers the SOS response in L. monocytogenes.

\section{METHODS}

Strains and sample conditions. L. monocytogenes EGD-e (Glaser et al., 2001) was grown in brain heart infusion (BHI) broth (Difco) with shaking (200 r.p.m., New Brunswick C24KC) using $10 \mathrm{ml}$ culture medium in $100 \mathrm{ml}$ conical flasks. An exponentially growing culture was used to inoculate $100 \mathrm{ml}$ fresh pre-warmed BHI broth in a $500 \mathrm{ml}$ flask. This culture was incubated at $37{ }^{\circ} \mathrm{C}$ with agitation at 200 r.p.m. until $\mathrm{OD}_{600} 1.0$ was reached. At this point (designated time zero) a $5 \mathrm{ml}$ aliquot was removed for RNA extraction and $10 \mathrm{ml}$ aliquots were transferred to pre-warmed $100 \mathrm{ml}$ flasks at $48{ }^{\circ} \mathrm{C}$. The cultures were incubated in a shaking water bath at $48{ }^{\circ} \mathrm{C}$ (GFL type 1083, 60\% shaking speed), and samples for RNA extraction and microscopic analysis were taken after 3, 10, 20 and $40 \mathrm{~min}$.

RNA isolation, labelling, hybridization, imaging and microarray analysis. Samples $(0.5 \mathrm{ml})$ were rapidly removed and diluted in $1.0 \mathrm{ml}$ RNAprotect (Qiagen). After incubation for $5 \mathrm{~min}$ at room temperature and centrifugation at $5000 \mathrm{~g}$ for $5 \mathrm{~min}$ pellets were stored at $-80{ }^{\circ} \mathrm{C}$. Microarray experiments (including microarray generation, total RNA extraction, labelling, hybridization, imaging and microarray analysis) were performed as described in detail previously (Chatterjee et al., 2006). The Significance Analysis of Microarrays (SAM) program was used to analyse the data. The cut-off for significantly differentially expressed genes was set with a $q$ value (false discovery rate) of $\leqslant 1 \%$ and a fold-change of $\geqslant 2$. In three independent experiments, the whole-genome expression profiles of cells that had undergone heat shock for 3, 10, 20 and 40 min were compared with those of cells at time zero in a dye-swap hybridization experiment.

Microscopy and image analysis. Samples $(1 \mathrm{ml})$ were removed from cultures (see above) and centrifuged at $5000 \mathrm{~g}$ for $2 \mathrm{~min}$. Cells were dissolved in nigrosin solution (Sigma-Aldrich) and dried on glass slides. Images of the cells were taken at $\times 100$ magnification with a Dialux 20 microscope (Leica). The ImageJ program (http:// rsb.info.nih.gov/ij/download.html) was used to analyse the images. The images were loaded in eight-bit type and the threshold was adjusted to black and white. The number of pixels per cell was counted and distribution graphs were constructed in Excel (Microsoft) by analyses of seven images from two cell preparations for each time point.

Quantitative PCR (Q-PCR). Superscript III reverse transcriptase (Invitrogen) was used to synthesize first-strand cDNA using $1 \mu \mathrm{g}$ DNase-treated total RNA. RNA samples were controlled for DNA contamination by omitting this cDNA synthesis step. Q-PCR reactions were performed using $10 \mu \mathrm{l} 2 \times$ Sybr Green PCR Master Mix (Applied Biosystems), $200 \mathrm{nM}$ primers and $1 \mu \mathrm{l}$ cDNA sample in a $20 \mu \mathrm{l}$ final volume. For each primer set a standard curve was generated using both genomic DNA and cDNA, and negative control samples using pure water were included. Reactions were run on the 7500 Real-Time PCR system (Applied Biosystems) with an initial step of $10 \mathrm{~min}$ at $95{ }^{\circ} \mathrm{C}$, and 40 cycles of $15 \mathrm{~s}$ at $95{ }^{\circ} \mathrm{C}$ and $1 \mathrm{~min}$ at $60^{\circ} \mathrm{C}$. To verify single-product formation, a dissociation cycle was added. Forward and reverse primers (Supplementary Table S1) were designed with an amplicon length of about $100 \mathrm{bp}$ and a Netprimer rating (http://www.premierbiosoft.com/netprimer) of above 80 . 


\section{RESULTS}

\section{Global gene expression analysis}

Whole-genome expression profiles of cells at four time points $(3,10,20$ and $40 \mathrm{~min}$ ) following the temperature shift from 37 to $48{ }^{\circ} \mathrm{C}$ were compared with those from cells harvested prior to the upshift (time zero). In total, 714 genes showed more than twofold differential expression at one or more of the four time points compared with the time zero samples with a q value $\leqslant 1 \%$ (significant values are given in Supplementary Table S2). Of these 714 genes, 427 showed increased expression and 287 showed decreased expression upon heat shock, constituting 15 and $10 \%$ of the total of 2857 genes, respectively. The maximum level of gene induction observed was 50.3-fold (lmo1883), while the maximum level of gene repression was 31.6-fold (lmo0048). Most of the differentially expressed genes showed a transient pattern. The highest number of differentially expressed genes, which account for $24 \%$ of all genes, was observed $3 \mathrm{~min}$ after the temperature upshift. After $40 \mathrm{~min}$, only $2 \%$ of all genes were differentially expressed. The differentially expressed genes were grouped into functional classes (Fig. 1). The classes containing the highest numbers of differentially expressed genes were carbohydrate transport and metabolism, amino-acid transport and metabolism, transcription and translation, with 84, 63, 59 and 52 genes, respectively. Most genes involved in carbohydrate transport and metabolism $(82 \%)$ and transcription $(81 \%)$ showed upregulation, and most genes involved in translation (92\%) showed downregulation. Numerous genes belonging to the amino-acid transport and metabolism class showed differential expression, both up- and down-regulation (36 and 27 genes, respectively).

\section{Stress response}

The L. monocytogenes genome encodes different classes of (heat) stress-response genes and general mechanisms to survive a wide variety of environmental insults. During exposure to elevated temperatures these classes of genes show differential expression of a constant or transient nature. The number of differentially expressed genes belonging to different classes that are significantly upregulated and down-regulated at the measured time points is shown in Table 1. A detailed list of the differentially expressed genes belonging to these different classes is presented in Table 2 and described further below.

\section{Stress-response genes}

The specific heat-shock regulons, consisting of class I (molecular chaperones) and class III (ATP-dependent proteases) heat-shock genes, were induced during the heat-shock experiments. Genes belonging to the class I heat-shock response [dnaJ, dnaK, grpE and $h r c A$ (lmo1472lmo1475), and groEL and groES (lmo2068 and lmo2069)] showed between twofold and fourfold higher expression levels. In contrast, the class III heat-shock genes [ctsR (lmo0229), lmo0230, lmo0231, clpC (lmo0232), clpE (lmo0997), lmo1138, clpY (lmo1279), clpB (lmo2206) and clpP (lmo2468)] showed a transient differential expression pattern. Another transiently expressed gene [htrA (lmo0292)], encoding a serine protease, showed approximately fivefold higher expression levels (Supplementary Table S2). This protease does not belong to the class III heat-shock genes but to a general group of stress genes. Helmann et al. (2001) also detected fivefold induction of two htrA paralogues in Bacillus subtilis, and designated this general class of heat-shock genes class $\mathrm{U}$.

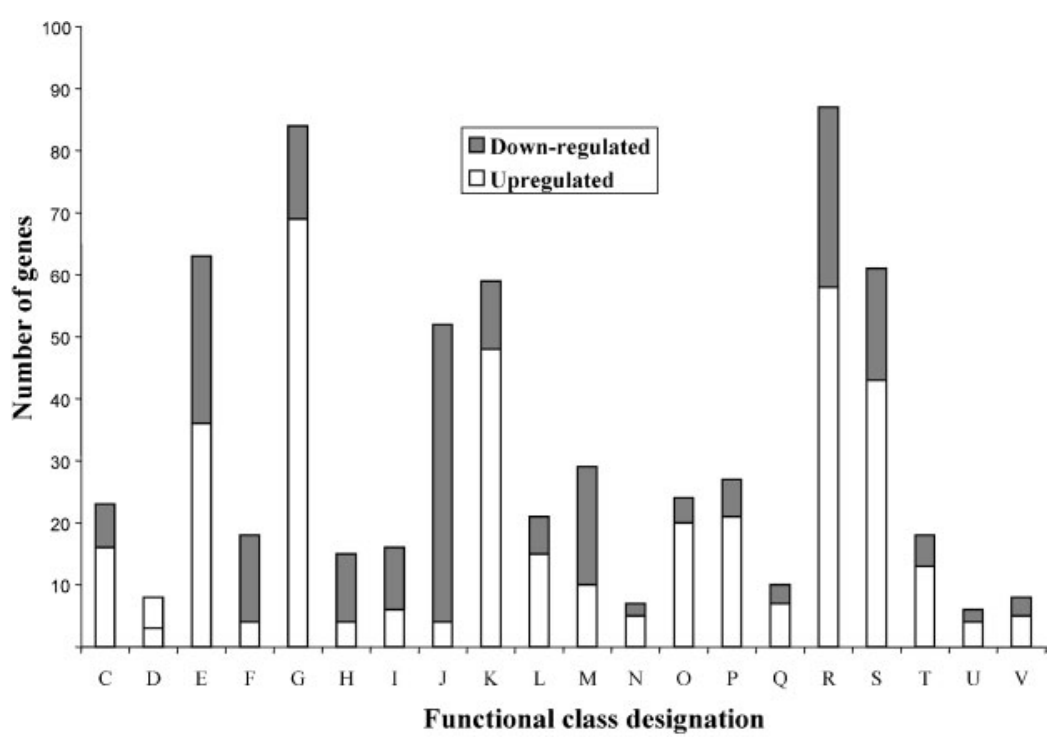

http://mic.sgmjournals.org
Fig. 1. Differentially expressed genes (foldchange $\geqslant 2$, $q$ value $\leqslant 1 \%$ ) grouped by functional classification according to the NCBI database (www.ncbi.nlm.nih.gov/COG/). Columns: $\mathrm{C}$, energy production and conversion; $D$, cell cycle control, mitosis and meiosis; $E$, amino-acid transport and metabolism; $F$, nucleotide transport and metabolism; G, carbohydrate transport and metabolism; $\mathrm{H}$, coenzyme transport and metabolism; I, lipid transport and metabolism; J, translation; $\mathrm{K}$, transcription; L, replication, recombination and repair; $M$, cell wall/membrane biogenesis; $\mathrm{N}$, cell motility; $\mathrm{O}$, post-translational modification, protein turnover and chaperones; $P$, inorganic ion transport and metabolism; $\mathrm{Q}$, secondary metabolite biosynthesis, transport and catabolism; R, general function prediction only; $\mathrm{S}$, function unknown; $\mathrm{T}$, signal transduction mechanisms; $\mathrm{U}$, intracellular trafficking and secretion; $\mathrm{V}$, defence mechanisms. 
Table 1. Numbers of up- and down-regulated genes of $L$. monocytogenes at designated time points after exposure to $48{ }^{\circ} \mathrm{C}$ in comparison with time zero expression at $37^{\circ} \mathrm{C}$

Numbers are shown of up- and down-regulated genes that belong to different classes of the (heat) stress response and general mechanisms that are important for surviving a wide variety of environmental insults. Up, upregulated; down, down-regulated.

\begin{tabular}{|c|c|c|c|c|c|c|c|c|}
\hline \multirow[t]{3}{*}{ Response } & \multicolumn{8}{|c|}{ Time point after exposure to $48^{\circ} \mathrm{C}$} \\
\hline & \multicolumn{2}{|c|}{$3 \mathrm{~min}$} & \multicolumn{2}{|c|}{$10 \mathrm{~min}$} & \multicolumn{2}{|c|}{$20 \mathrm{~min}$} & \multicolumn{2}{|c|}{$40 \mathrm{~min}$} \\
\hline & Up & Down & Up & Down & Up & Down & Up & Down \\
\hline Group I heat shock & 6 & 0 & 2 & 0 & 6 & 0 & 5 & 0 \\
\hline Group III heat shock & 9 & 0 & 4 & 0 & 6 & 0 & 4 & 0 \\
\hline Group II stress & 54 & 0 & 33 & 0 & 21 & 0 & 5 & 0 \\
\hline SOS response and DNA repair & 7 & 0 & 4 & 0 & 7 & 0 & 8 & 0 \\
\hline Cell division & 0 & 12 & 0 & 2 & 0 & 1 & 0 & 0 \\
\hline Autolysis and cell wall hydrolases & 0 & 8 & 0 & 3 & 0 & 3 & 0 & 1 \\
\hline Cell wall synthesis & 7 & 7 & 3 & 4 & 3 & 4 & 2 & 4 \\
\hline Cell wall associated & 6 & 2 & 1 & 1 & 3 & 0 & 0 & 0 \\
\hline Virulence associated & 3 & 4 & 1 & 3 & 2 & 4 & 2 & 4 \\
\hline
\end{tabular}

The class II stress response represents a general stressresponse mechanism that is regulated by the alternative sigma factor SigB. The gene encoding SigB (lmo0895) did not show more than twofold differential expression on the microarrays during heat shock. Verification of $\operatorname{sig} B$ expression using Q-PCR showed 1.5-fold upregulation after 3 and $10 \mathrm{~min}$ (Fig. 2). In total, 51 genes previously identified as being SigB-regulated (Kazmierczak et al., 2003) showed increased expression at one or more of the selected time points. Among these upregulated genes were ctc (lmo0211), lmo1601 and $y d a G$ (lmo2748). These genes encode proteins that show sequence similarity with general stress proteins. Increased expression was also observed for the SigB-regulated $о p u C$ operon (lmo1425-lmo1428). This operon encodes a betaine/carnitine/choline ABC transporter and has previously been shown to be responsible for the accumulation of osmolytes in response to salt, acid and cold stress (Sleator et al., 2001; Wemekamp-Kamphuis et al., 2004). Notably, these osmolytes have also been shown to provide protection during heat exposure of $B$. subtilis (Holtmann \& Bremer, 2004) and Escherichia coli (Caldas et al., 1999), though no increase in their intracellular concentration was observed.

\section{SOS response and DNA repair}

The SOS response is a mechanism involved in the repair of DNA damage and restart of stalled replication forks (Maul \& Sutton, 2005) or in the introduction of adaptive point mutations (Michel, 2005; Miller et al., 2004). Numerous genes that are part of the SOS response and the DNA repair machinery showed increased expression after heat exposure. The recA (lmo1398) gene, encoding the major activator of the SOS response (RecA), showed a gradual increase in expression over time, from 1.4-fold to 5.2-fold induction between 3 and $40 \mathrm{~min}$. Differential expression of lexA (lmo1302), the repressor of the SOS response, was not observed using microarrays, but Q-PCR showed a change from 1.9 -fold repression at $3 \mathrm{~min}$ to 2.0 -fold induction at $40 \mathrm{~min}$ (Fig. 2). Transcription of $\operatorname{din} B$ (lmo1975) and umuDC (lmo2675 and lmo2676), coding for DNA polymerases IV and V, respectively, was also upregulated. These gene products constitute important alternative polymerases in the SOS response. The genes encoding the DNA repair proteins $\operatorname{radA}(\operatorname{lmo} 0233), \operatorname{rec} N$ (lmo1368), uvrA (lmo2488) and $u v r B$ (lmo2489) showed increased expression as well. Two other genes belonging to the SOS response were induced, namely ynzC (lmo0496) and yneA (lmo1303). The latter is transcribed divergently from $\operatorname{lex} A$ and the product has been shown to be responsible for cell elongation and suppression of cell division (Kawai et al., 2003). Thus, the expression of $y n e A$ is consistent with the observation that exposure of L. monocytogenes to elevated temperatures results in elongated cells (Fig. 3). After exposure of cells growing at $37{ }^{\circ} \mathrm{C}$ to a temperature of $48{ }^{\circ} \mathrm{C}$, the $\mathrm{OD}_{600}$ continued to increase (Fig. 3a), whereas the concentration of cells (c.f.u. $\mathrm{ml}^{-1}$ ) was found to remain constant (Fig. 3b). Cell size measurements of microscopic images showed increased cell size with time after heat exposure compared with cells that were grown continuously at $37{ }^{\circ} \mathrm{C}$ (Fig. 3c-e).

\section{Cell division}

Cell division is a complicated mechanism involving different pathways that are intertwined. The expression of two genes, $1 \mathrm{mo} 2687$ and $1 \mathrm{mo} 2688$, encoding proteins that show sequence similarity to the cell division protein FtsW, was induced after $3 \mathrm{~min}$ exposure to $48{ }^{\circ} \mathrm{C}$. Ten other genes involved in cell division showed reduced expression, mainly in the initial phase of the heat shock. Repression of the genes lmo1071, minDE (lmo1544 and lmo1545), mreDCB (lmo1546-lmo1548), divIVA (lmo2020) and $p b p B$ (lmo2039), encoding proteins similar to RodA and 
Table 2. Differentially expressed genes of $L$. monocytogenes EGD-e at designated time points after exposure to $48{ }^{\circ} \mathrm{C}$ in comparison with time zero expression at $37^{\circ} \mathrm{C}$

Significant values ( $\mathrm{q}$ value $\leqslant 1 \%$ and fold-change $\geqslant 2$ ) are given in bold type.

\begin{tabular}{|c|c|c|c|c|c|c|}
\hline \multirow[t]{2}{*}{ Gene } & \multicolumn{4}{|c|}{ Fold-change at time (min) } & \multirow[t]{2}{*}{ Gene designation } & \multirow[t]{2}{*}{ Description of product } \\
\hline & 3 & 10 & 20 & 40 & & \\
\hline \multicolumn{7}{|c|}{$\begin{array}{l}\text { Class I heat-shock } \\
\text { genes }\end{array}$} \\
\hline $\operatorname{lmo} 1472$ & 2.67 & 1.64 & 2.15 & 2.50 & $d n a J$ & Heat-shock protein DnaJ \\
\hline $\operatorname{lmo} 1473$ & 3.14 & 1.94 & 2.52 & 2.41 & $d n a K$ & Heat-shock protein (molecular chaperone) DnaK \\
\hline $\operatorname{lmo} 1474$ & 2.97 & 1.48 & 2.06 & 2.10 & $\operatorname{grpE}$ & Heat-shock protein GrpE \\
\hline $\operatorname{lmo} 1475$ & 3.04 & 1.81 & 2.42 & 2.30 & $h r c A$ & Transcription repressor of class I heat-shock genes HrcA \\
\hline $\operatorname{lmo} 2068$ & 2.96 & 2.97 & 2.96 & 2.71 & groEL & Heat-shock protein (chaperone) GroEL \\
\hline $\operatorname{lmo} 2069$ & 3.06 & 2.66 & 3.26 & 2.94 & groES & Heat-shock protein (chaperone) GroES \\
\hline \multicolumn{7}{|c|}{$\begin{array}{l}\text { Class III } \\
\text { heat-shock genes }\end{array}$} \\
\hline $\operatorname{lmo} 0229$ & 2.95 & 1.02 & 1.13 & 1.22 & & Transcription repressor of class III heat-shock genes CtsR \\
\hline $\operatorname{lmo} 0230$ & 4.98 & 1.13 & 1.57 & 1.56 & & Similar to B. subtilis YacH protein \\
\hline $\operatorname{lmo} 0231$ & 8.12 & 1.81 & 2.27 & 1.95 & & Similar to arginine kinase \\
\hline $\operatorname{lmo} 0232$ & 6.86 & 1.74 & 2.23 & 2.14 & $c l p C$ & Endopeptidase Clp ATP-binding chain C \\
\hline $\operatorname{lmo} 0997$ & 29.01 & 3.42 & 4.37 & 3.32 & $c l p E$ & ATP-dependent protease \\
\hline $\operatorname{lmo} 1138$ & 7.10 & 2.75 & 3.13 & 2.49 & & Similar to ATP-dependent Clp protease \\
\hline $\operatorname{lmo} 1279$ & 1.97 & 1.28 & 1.18 & -1.07 & clpY; hslU & Highly similar to ATP-dependent Clp protease-like proteins \\
\hline $\operatorname{lmo} 2206$ & 16.12 & 8.20 & 6.42 & 4.00 & $\operatorname{clp} B$ & Similar to endopeptidase Clp ATP-binding chain B \\
\hline $\operatorname{lmo} 2468$ & 6.38 & 4.94 & 4.76 & 3.34 & clpP & ATP-dependent Clp protease, proteolytic subunit \\
\hline \multicolumn{7}{|c|}{$\begin{array}{l}\text { Class II stress } \\
\text { genes } \\
\text { (SigB regulated) }\end{array}$} \\
\hline $\operatorname{lmo} 0200$ & 6.63 & 4.29 & 5.06 & 4.35 & $\operatorname{prfA}$ & Listeriolysin positive regulatory protein \\
\hline $\operatorname{lmo} 0211$ & 2.32 & 1.22 & 1.50 & 1.36 & $c t c$ & Similar to B. subtilis general stress protein \\
\hline $\operatorname{lmo} 0405$ & 5.69 & 1.54 & 1.16 & -1.01 & & Similar to phosphate transport protein \\
\hline $\operatorname{lmo} 0593$ & 2.04 & 1.50 & -1.04 & -1.25 & & Similar to transport proteins \\
\hline $\operatorname{lmo} 0669$ & 5.30 & 1.17 & 1.66 & 1.30 & & Similar to oxidoreductase \\
\hline $\operatorname{lmo} 0670$ & 6.49 & 1.17 & 1.74 & 1.23 & & Hypothetical protein \\
\hline $\operatorname{lmo} 0781$ & 5.30 & 1.49 & 1.30 & -1.17 & & Similar to mannose-specific PTS ${ }^{*}$ component IID \\
\hline $\operatorname{lmo} 0782$ & 4.83 & 1.56 & 1.33 & -1.16 & & Similar to mannose-specific PTS component IIC \\
\hline $\operatorname{lmo} 0783$ & 6.08 & 1.83 & 1.47 & -1.24 & & Similar to mannose-specific PTS component IIB \\
\hline $\operatorname{lmo} 0794$ & 11.61 & 2.03 & 1.77 & 1.01 & & Similar to B. subtilis YwnB protein \\
\hline $\operatorname{lmo} 0880$ & 8.15 & 1.43 & 1.37 & -1.13 & & Similar to wall-associated-protein precursor (LPXTG motif) \\
\hline $\operatorname{lmo} 0911$ & 9.90 & 2.10 & 2.36 & 1.20 & & Hypothetical protein \\
\hline $\operatorname{lmo} 0956$ & 7.93 & 3.30 & 4.29 & 2.80 & & Similar to $\mathrm{N}$-acetylglucosamine-6-phosphate deacetylase \\
\hline $\operatorname{lmo} 0957$ & 7.19 & 2.52 & 3.33 & 2.41 & $n a g B$ & Similar to glucosamine-6-phosphate isomerase \\
\hline $\operatorname{lmo} 0958$ & 5.39 & 2.56 & 3.27 & 2.47 & & Similar to transcription regulator (GntR family) \\
\hline $\operatorname{lmo} 0994$ & 6.59 & 1.59 & 1.62 & -1.11 & & Hypothetical protein \\
\hline $\operatorname{lmo} 1421$ & 3.03 & 1.19 & 1.15 & -1.02 & bilEA & Bile-exclusion system \\
\hline $\operatorname{lmo} 1425$ & 5.01 & 2.52 & 1.56 & -1.34 & opuCD & $\begin{array}{l}\text { Similar to betaine-carnitine-choline } \mathrm{ABC} \text { transporter } \\
\text { (membrane protein) }\end{array}$ \\
\hline $\operatorname{lmo} 1426$ & 5.09 & 2.03 & 1.58 & -1.27 & ориСC & $\begin{array}{l}\text { Similar to glycine betaine-carnitine-choline } \mathrm{ABC} \\
\text { transporter (osmoprotectant-binding protein) }\end{array}$ \\
\hline $\operatorname{lmo} 1427$ & 5.54 & 1.49 & 1.35 & -1.27 & ориСB & $\begin{array}{l}\text { Similar to glycine betaine-carnitine-choline ABC } \\
\text { transporter (membrane protein) }\end{array}$ \\
\hline $\operatorname{lmo} 1428$ & 4.86 & 1.44 & 1.28 & -1.36 & opuCA & $\begin{array}{l}\text { Similar to glycine betaine-carnitine-choline ABC } \\
\text { transporter (ATP-binding protein) }\end{array}$ \\
\hline $\operatorname{lmo} 1433$ & 4.10 & 1.27 & 1.42 & -1.19 & & Similar to glutathione reductase \\
\hline $\operatorname{lmo} 1538$ & 4.93 & 1.09 & 1.12 & -1.15 & $g l p K$ & Similar to glycerol kinase \\
\hline $\operatorname{lmo} 1539$ & 7.02 & 1.70 & 1.41 & -1.04 & & Similar to glycerol uptake facilitator \\
\hline $\operatorname{lmo} 1580$ & 2.85 & -1.01 & -1.14 & -1.33 & & Similar to unknown protein \\
\hline $\operatorname{lmo} 1601$ & 2.79 & 2.63 & 2.03 & -1.48 & & Similar to general stress protein \\
\hline
\end{tabular}


Table 2. cont.

\begin{tabular}{|c|c|c|c|c|c|c|}
\hline \multirow[t]{2}{*}{ Gene } & \multicolumn{4}{|c|}{ Fold-change at time (min) } & \multirow[t]{2}{*}{ Gene designation } & \multirow[t]{2}{*}{ Description of product } \\
\hline & 3 & 10 & 20 & 40 & & \\
\hline $\operatorname{lmo} 1602$ & 3.03 & 1.94 & 1.46 & -1.38 & & Similar to unknown protein \\
\hline $\operatorname{lmo} 1694$ & 8.96 & 3.48 & 2.27 & 1.18 & & Similar to CDP-abequose synthase \\
\hline $\operatorname{lmo} 1883$ & 50.28 & 2.48 & 3.22 & 2.18 & & Similar to chitinases \\
\hline $\operatorname{lmo} 2067$ & 8.22 & 3.22 & 2.88 & 1.84 & & Similar to conjugated bile acid hydrolase \\
\hline $\operatorname{lmo} 2085$ & 10.81 & 2.38 & 2.02 & 1.43 & & Putative peptidoglycan-bound protein (LPXTG motif) \\
\hline $\operatorname{lmo} 2157$ & 10.54 & 3.76 & 5.04 & 1.12 & sepA & SepA \\
\hline $\operatorname{lmo} 2205$ & 11.94 & 7.47 & 5.55 & 3.05 & $g p m A$ & Similar to phosphoglyceromutase 1 \\
\hline $\operatorname{lmo} 2230$ & 10.95 & 5.12 & 4.59 & 2.44 & & Similar to arsenate reductase \\
\hline $\operatorname{lmo} 2269$ & 2.66 & 2.14 & 2.36 & 2.17 & & Hypothetical protein \\
\hline $\operatorname{lmo} 2386$ & 10.34 & 2.02 & 1.92 & 1.42 & & Similar to B. subtilis YuiD protein \\
\hline $\operatorname{lmo} 2391$ & 15.53 & 2.35 & 1.72 & -1.06 & & Similar to B. subtilis conserved hypothetical protein $\mathrm{YhfK}$ \\
\hline $\operatorname{lmo} 2398$ & 3.93 & 1.99 & 1.48 & 1.01 & $\operatorname{ltrC}$ & Low-temperature-requirement $\mathrm{C}$ protein \\
\hline $\operatorname{lmo} 2434$ & 19.43 & 2.79 & 2.24 & 1.51 & & Highly similar to glutamate decarboxylases \\
\hline $\operatorname{lmo} 2463$ & 12.75 & 2.89 & 1.82 & 1.19 & & Similar to transport protein \\
\hline $\operatorname{lmo} 2484$ & 11.91 & 2.62 & 2.58 & 1.34 & & Similar to B. subtilis YvlD protein \\
\hline $\operatorname{lmo} 2485$ & 9.04 & 2.35 & 2.18 & 1.36 & & Similar to B. subtilis YvlC protein \\
\hline $\operatorname{lmo} 2511$ & 4.39 & 1.71 & 1.27 & -1.18 & & Similar to B. subtilis conserved hypothetical protein YvyD \\
\hline $\operatorname{lmo} 2570$ & 11.65 & 3.04 & 2.40 & 1.41 & & Hypothetical protein \\
\hline $\operatorname{lmo} 2571$ & 12.60 & 3.13 & 2.37 & 1.37 & & Similar to nicotinamidase \\
\hline $\operatorname{lmo} 2572$ & 15.24 & 2.86 & 2.07 & 1.40 & & Similar to chain A, dihydrofolate reductase \\
\hline $\operatorname{lmo} 2573$ & 15.86 & 3.11 & 2.53 & 1.23 & & Similar to zinc-binding dehydrogenase \\
\hline $\operatorname{lmo} 2602$ & 7.66 & 2.16 & 1.69 & 1.14 & & Conserved hypothetical protein \\
\hline $\operatorname{lmo} 2673$ & 12.77 & 3.36 & 2.73 & 1.61 & & Conserved hypothetical protein \\
\hline $\operatorname{lmo} 2695$ & 13.84 & 3.91 & 2.27 & -1.13 & & Similar to dihydroxyacetone kinase \\
\hline $\operatorname{lmo} 2696$ & 13.56 & 3.06 & 1.90 & -1.11 & & Similar to hypothetical dihydroxyacetone kinase \\
\hline $\operatorname{lmo} 2697$ & 11.82 & 3.00 & 2.00 & -1.22 & & Hypothetical protein \\
\hline $\operatorname{lmo} 2748$ & 11.87 & 2.34 & 1.68 & 1.07 & & Similar to B. subtilis stress protein $\mathrm{YdaG}$ \\
\hline \multicolumn{7}{|c|}{$\begin{array}{l}\text { SOS response and } \\
\text { DNA repair }\end{array}$} \\
\hline $\operatorname{lmo} 0233$ & 3.32 & 1.04 & 1.19 & 1.29 & $\operatorname{radA} ;$ sms & Similar to DNA repair protein Sms \\
\hline $\operatorname{lmo} 0496$ & 6.51 & 3.58 & 5.04 & 3.36 & $y n z C$ & Similar to YnzC of B. subtilis \\
\hline $\operatorname{lmo} 1303$ & 2.48 & 1.27 & 3.14 & 5.15 & & Similar to B. subtilis YneA protein \\
\hline $\operatorname{lmo} 1368$ & 2.00 & 1.14 & 1.11 & 1.10 & $\operatorname{recN}$ & DNA repair and genetic recombination \\
\hline $\operatorname{lmo} 1398$ & 1.40 & 2.29 & 4.47 & 5.23 & $\operatorname{rec} A$ & Recombination protein RecA \\
\hline $\operatorname{lmo} 1975$ & 3.99 & 3.15 & 4.53 & 5.52 & $\operatorname{din} B$ & DNA polymerase IV \\
\hline $\operatorname{lmo} 2488$ & 2.29 & 2.15 & 2.55 & 4.54 & $u v r A$ & Excinuclease ABC (subunit A) \\
\hline $\operatorname{lmo} 2489$ & 2.65 & 2.26 & 3.60 & 5.24 & $u v r B$ & Excinuclease ABC (subunit B) \\
\hline $\operatorname{lmo} 2675$ & 1.82 & 1.38 & 2.00 & 2.90 & $u m u D$ & DNA polymerase $\mathrm{V}$ \\
\hline $\operatorname{lmo} 2676$ & 1.60 & 1.30 & 1.41 & 2.60 & umuC & DNA polymerase $\mathrm{V}$ \\
\hline \multicolumn{7}{|c|}{ Cell division } \\
\hline $\operatorname{lmo} 2687$ & 3.40 & 1.14 & 1.24 & 1.50 & & Similar to cell-division protein FtsW \\
\hline $\operatorname{lmo} 2688$ & 3.56 & 1.12 & 1.27 & 1.59 & & Similar to cell-division protein FtsW \\
\hline $\operatorname{lmo} 1071$ & -2.09 & -1.17 & -1.24 & -1.02 & & Similar to cell-division protein RodA and FtsW \\
\hline $\operatorname{lmo} 1544$ & -2.45 & -1.44 & -1.57 & -1.65 & $\min D$ & Highly similar to septum placement protein MinD \\
\hline $\operatorname{lmo} 1545$ & -3.25 & -1.80 & -1.95 & -2.02 & $\min C$ & Similar to septum placement protein MinC \\
\hline $\operatorname{lmo} 1546$ & -3.52 & -1.45 & -1.33 & -1.58 & $m r e D$ & Similar to cell-shape-determining protein MreD \\
\hline $\operatorname{lmo} 1547$ & -2.98 & -1.55 & -1.70 & -1.81 & mreC & Similar to cell-shape-determining protein $\mathrm{MreC}$ \\
\hline $\operatorname{lmo} 1548$ & -2.86 & -1.46 & -1.75 & -1.64 & $m r e B$ & Similar to cell-shape-determining protein MreB \\
\hline $\operatorname{lmo} 2020$ & -4.32 & -1.62 & -1.94 & -1.88 & $\operatorname{divIVA}$ & Similar to cell-division initiation protein \\
\hline $\operatorname{lmo} 2039$ & -2.36 & -1.23 & -1.39 & -1.41 & $p b p B$ & $\begin{array}{l}\text { Similar to penicillin-binding protein } 2 \mathrm{~B} \text {, cell-division } \\
\text { protein FtsI (penicillin-binding protein } 3 \text { ) }\end{array}$ \\
\hline $\operatorname{lmo} 2506$ & -10.3 & -2.67 & -2.34 & -1.33 & $f t s X$ & Highly similar to cell-division protein FtsX \\
\hline $\operatorname{lmo} 2507$ & -11.4 & -2.68 & -2.30 & -1.35 & $f t s E$ & Highly similar to cell-division ATP-binding protein FtsE \\
\hline
\end{tabular}


Table 2. cont.

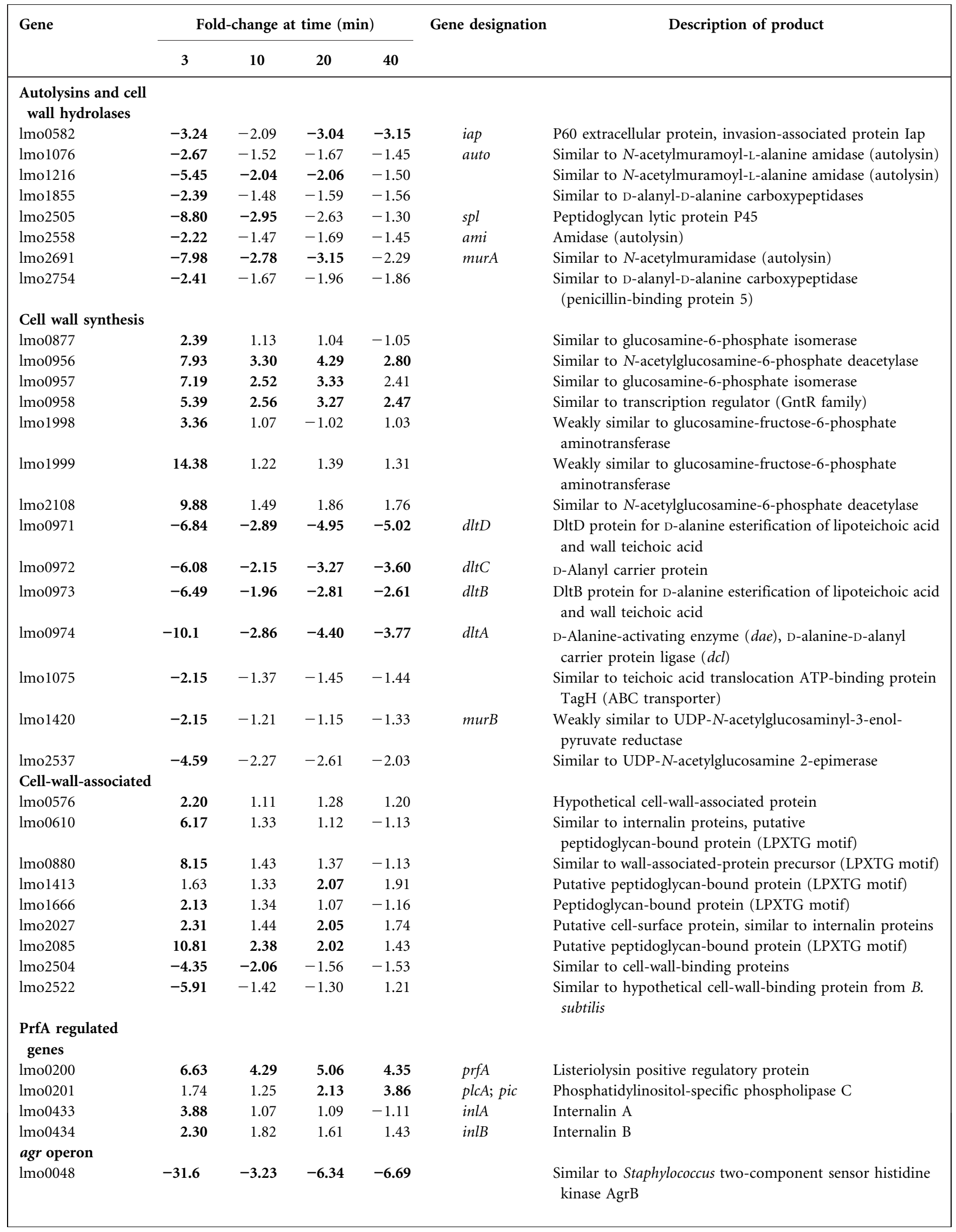


Table 2. cont.

\begin{tabular}{|c|c|c|c|c|c|c|}
\hline \multirow[t]{2}{*}{ Gene } & \multicolumn{4}{|c|}{ Fold-change at time (min) } & \multirow[t]{2}{*}{ Gene designation } & \multirow[t]{2}{*}{ Description of product } \\
\hline & 3 & 10 & 20 & 40 & & \\
\hline $\operatorname{lmo} 0049$ & -19.4 & -3.84 & -5.84 & -8.11 & & Similar to Staphylococcus two-component protein AgrD \\
\hline $\operatorname{lmo} 0050$ & -11.8 & -2.39 & -3.68 & -3.80 & & $\begin{array}{l}\text { Similar to Staphylococcus two-component sensor histidine } \\
\text { kinase AgrC }\end{array}$ \\
\hline $\operatorname{lmo} 0051$ & -8.89 & -1.92 & -3.26 & -3.45 & & $\begin{array}{l}\text { Similar to two-component response regulator protein (AgrA } \\
\text { from Staphylococcus) }\end{array}$ \\
\hline
\end{tabular}

${ }^{\star}$ Phosphotransferase system.

FtsW, cell division inhibitors (septum placement), cell shape determining proteins, cell division initiation protein (septum placement), and cell division protein FtsI (penicillin-binding protein 3), respectively, was observed only after 3 min heat shock. Transcription of ftsX (lmo2506) and ftsE (lmo2507), whose products are highly similar to cell division protein FtsX and cell division ATP-binding protein FtsE, respectively, was transiently down-regulated for 10 and 20 min after heat exposure, respectively.

\section{Cell-wall-associated genes}

The bacterial cell wall is a complex structure and plays an important role as the first protection against environmental stresses. Cell wall hydrolases (including autolysins) play important roles in numerous cellular processes, including cell division and cell wall turnover. In line with the results described above, all genes encoding cell wall hydrolases, namely aut (lmo1076), lmo1216, lmo1855, spl (lmo2505), ami (lmo2558), murA (lmo2691) and lmo2754, showed a transiently repressed expression pattern, except for iap (lmo0582), which showed an almost constant threefold repression. The intermediate glucosamine-6phosphate plays a central role in the regulation of cell wall biosynthesis vs glycolysis (Komatsuzawa et al., 2004). Genes controlling the regulation between these two pathways showed induction after heat exposure. These genes are lmo0877 and lmo0957, for which the encoded products show sequence similarity to glucosamine-6-phosphate isomerases, $1 \mathrm{mo} 0956$ and $1 \mathrm{mo} 2108$, which encode putative $\mathrm{N}$-acetylglucosamine-6-phosphate deacetylases, and lmo1998 and lmo1999, which encode products that show low sequence similarity to glucosamine-fructose-6-phosphate aminotransferases. The essential gene in the biosynthetic pathway, $\operatorname{murB}$ (lmo1420), was down-regulated after 3 min heat shock. Another operon that plays a role in cell wall synthesis and showed decreased expression upon heat shock was the dlt operon (lmo0971-lmo0974), which encodes proteins important in catalysing the incorporation of D-alanine residues into lipoteichoic acids and wall teichoic acids. Furthermore, the 1 mo1075 gene, which encodes a protein with $64 \%$ sequence similarity to $B$. subtilis teichoic acid translocation ATP-binding protein TagH, was also down-regulated after 3 min of heat shock.
Nine genes encoding putative cell-wall-associated proteins were differentially expressed during heat exposure. Five of these genes encode products containing an LPXTG peptidoglycan-binding motif, namely lmo0610, lmo0880, lmo1413, lmo1666 and lmo2085.

\section{Virulence-associated genes}

A constant induction was observed for prfa (lmo0200), which encodes the major regulator of the virulence genes. This gene is both SigB- and SigA-regulated, and its product induces genes containing a PrfA box in their promoter sequence. Accordingly, numerous PrfA-regulated virulence genes (Milohanic et al., 2003) showed upregulation after heat exposure, including plcA (lmo0201), encoding a phospholipase, inlA and inlB (lmo0433 and lmo0434), encoding Listeria-specific internalins, lmo2067, encoding a conjugated bile acid hydrolase, and lmo0596, encoding an unknown protein. However, Rauch et al. (2005) have shown that PrfA has no direct influence on the transcription of lmo2067 and lmo0596. Significant down-regulation was found for the agr locus (lmo0048- lmo0051). This locus encodes a two-component system that has been shown to play a role in bacterial virulence (Autret et al., 2003).

\section{Validation of microarray gene expression}

The microarray data were validated by Q-PCR analysis using a set of 13 genes which cover a range of expression values in the microarray data. The relative gene expression levels obtained by Q-PCR were normalized to that of three genes ( $t p i, r p o B$ and the 16S rRNA gene) that did not show fluctuating expression during temperature changes. Relative quantitative values were obtained using the comparative threshold cycle method $\left(\Delta \Delta \mathrm{C}_{\mathrm{T}}\right)$ in which the $\mathrm{C}_{\mathrm{T}}$ value corresponds to the cycle at which the fluorescent signal crosses the threshold line. The relative expression of the genes was determined in quadruplicate for three independent temperature upshift experiments. The resulting ratios were $\log _{2}$ transformed and plotted against the $\log _{2}$ values from the microarray analysis. Fig. 2 shows a strong correlation, with $r>0.8$ for all time points, which is considered the threshold for strong correlation. Generally, 
The heat-shock response of Listeria monocytogenes
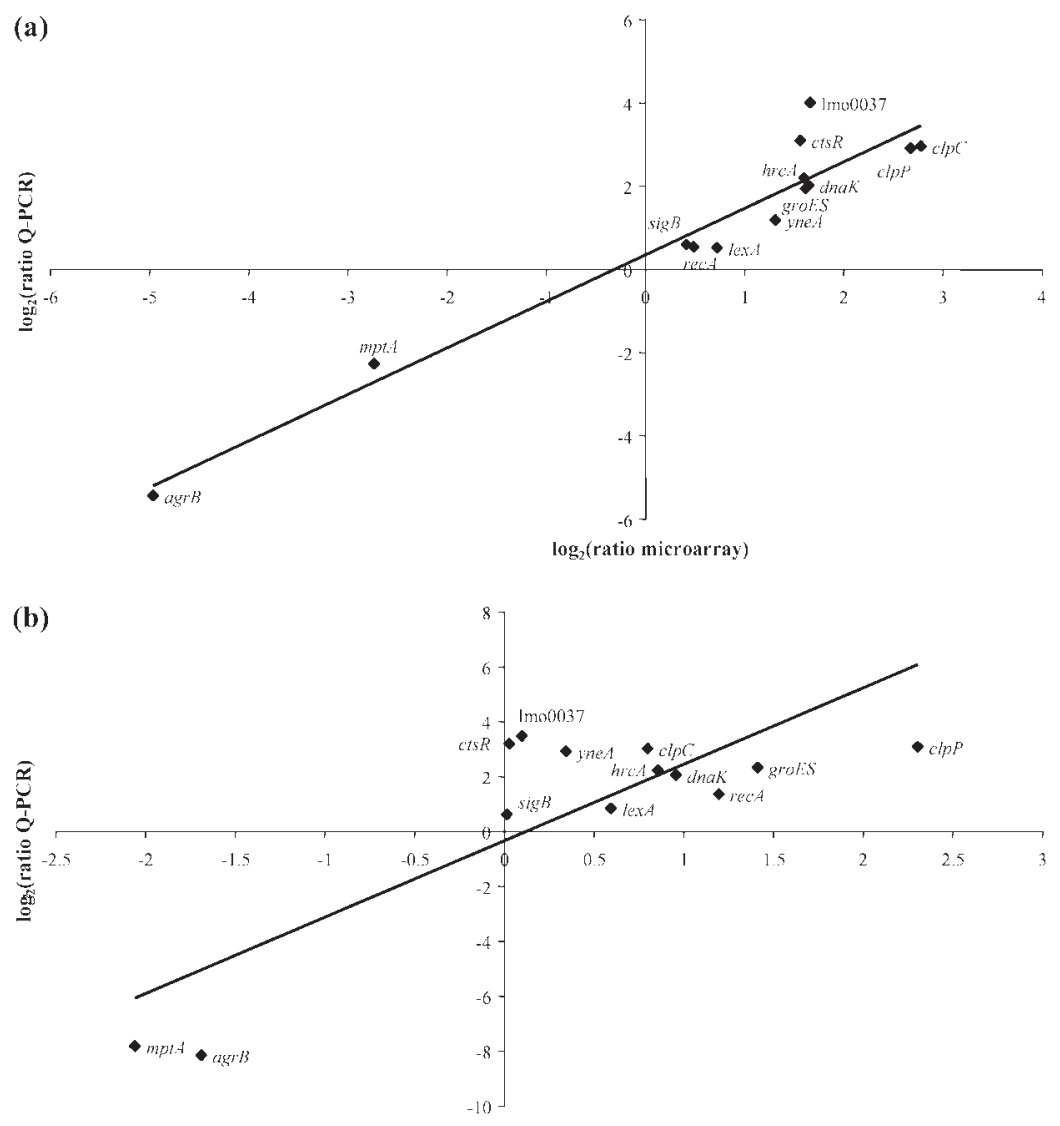

$\log _{2}$ (ratio microarray)
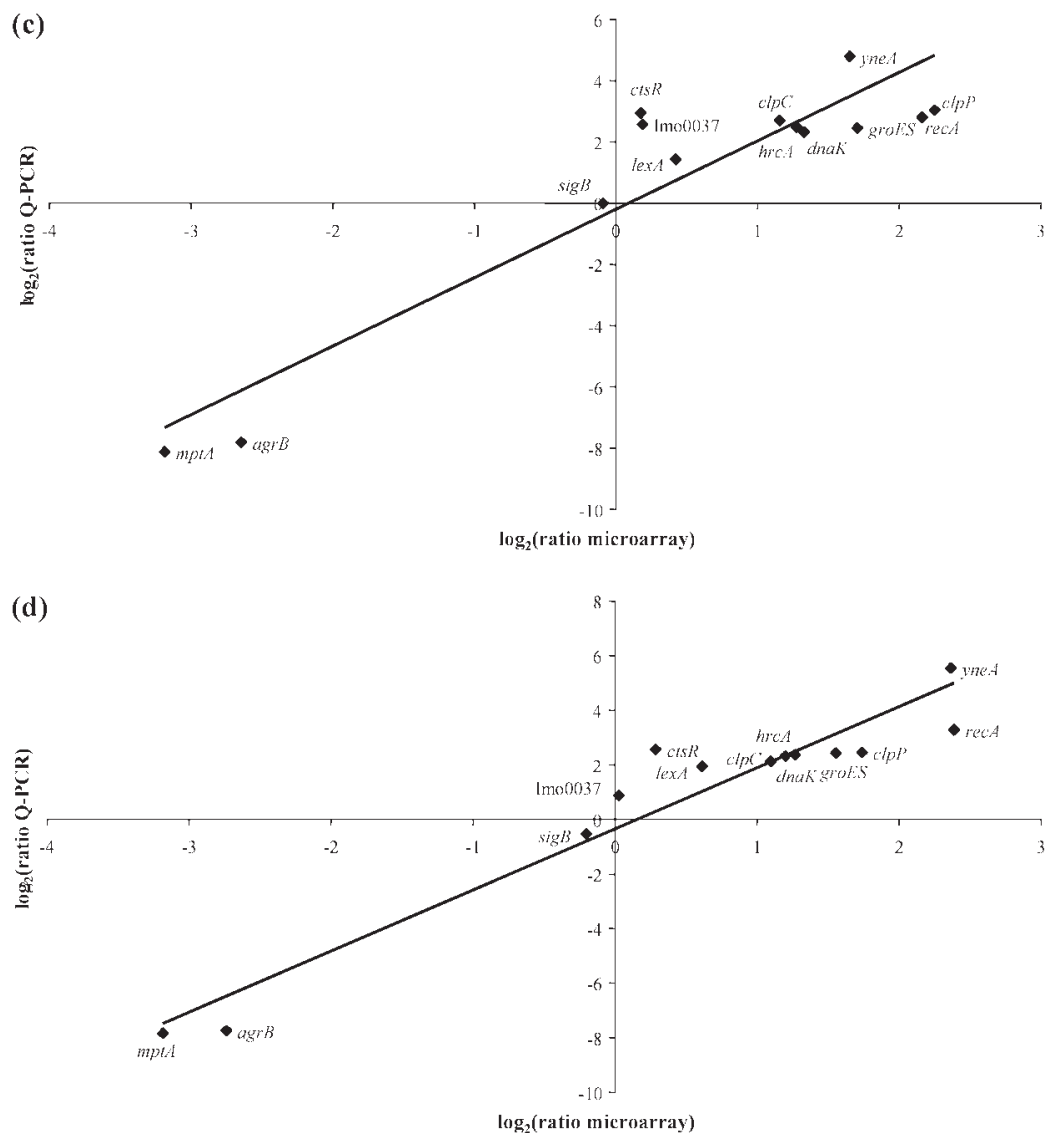

Fig. 2. Validation of microarray data by QPCR analysis. (a) Comparison of differentially expressed genes after $3 \mathrm{~min}$; (b) comparison of differentially expressed genes after $10 \mathrm{~min}$; (c) comparison of differentially expressed genes after $20 \mathrm{~min}$; (d) comparison of differentially expressed genes after $40 \mathrm{~min}$.

http://mic.sgmjournals.org

3601 
(a)

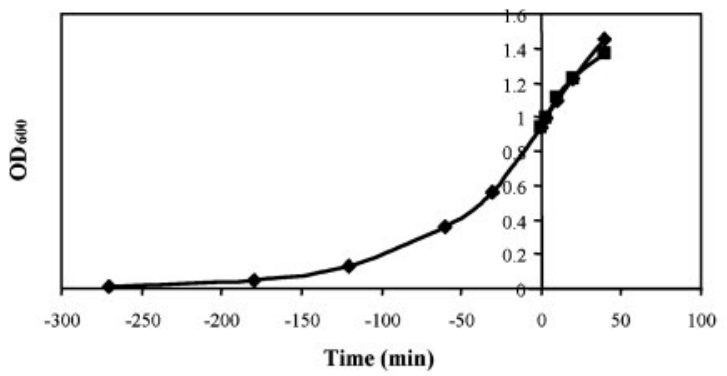

(b)

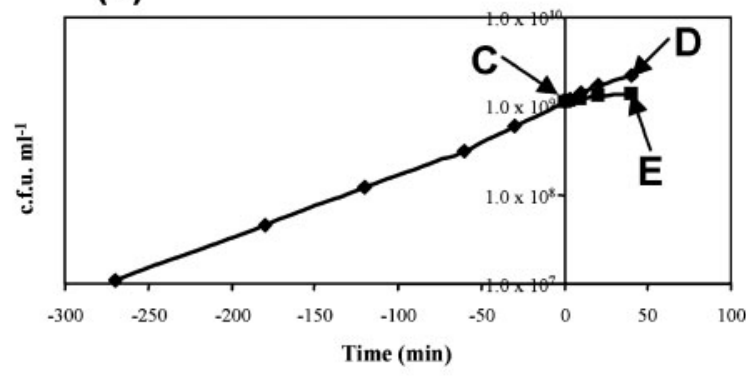

(C2)

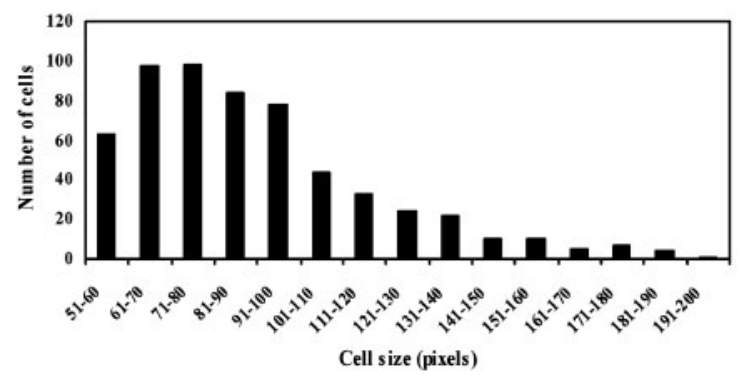

(D2)

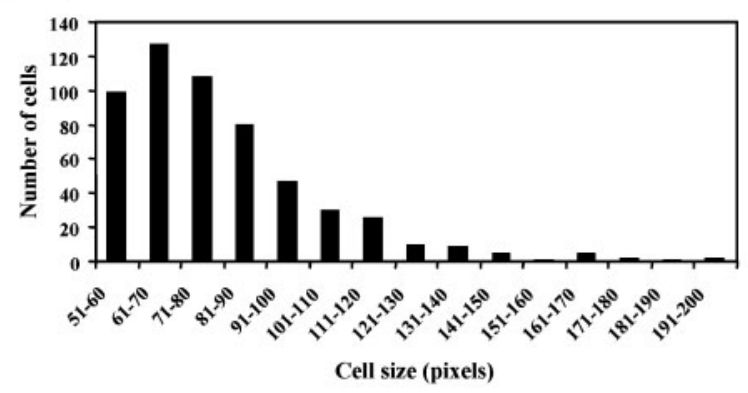

(E2)

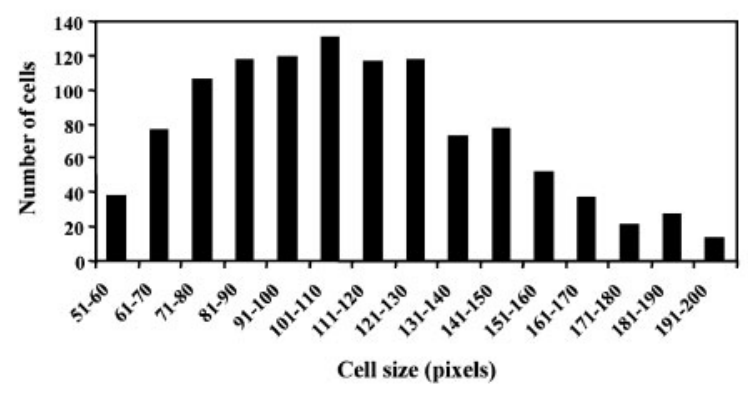

Fig. 3. Increasing cell size of L. monocytogenes cells exposed to $48{ }^{\circ} \mathrm{C}$ in comparison with cells continuously grown at $37{ }^{\circ} \mathrm{C}$. The $\mathrm{OD}_{600}(\mathrm{a})$ and viability count (b) of a $L$. monocytogenes culture grown at $37^{\circ} \mathrm{C}(\boldsymbol{})$ were measured. At time zero (point $\mathrm{C}$ ) the culture was transferred to $48{ }^{\circ} \mathrm{C}(\boldsymbol{\square})$ or grown on at $37{ }^{\circ} \mathrm{C}(\boldsymbol{)})$. The cultures were incubated for 40 min and samples were taken from the culture at $37{ }^{\circ} \mathrm{C}$ (point D) and from the culture at $48{ }^{\circ} \mathrm{C}$ (point E). C1, D1 and E1: microscopic images of the cells collected at points $C, D$ and $E$, respectively; C2, D2 and E2: analyses of microscopic images of cells at points C, D and E, respectively, using ImageJ. The graphs show the distribution of cell sizes in number of pixels per cell. 
the microarray analysis underestimated the differential expression values by an average of fivefold. Similar observations have been reported previously when using ORF arrays in microbial transcriptome analysis (Gao et al., 2004; Helmann et al., 2001; Stintzi, 2003).

\section{DISCUSSION}

Variation in temperature is frequently encountered in nature, and bacteria have evolved to cope with such fluctuations by employing various mechanisms. Microarrays were used to investigate the whole-genome expression profiles of $L$. monocytogenes in response to a temperature upshift from 37 to $48{ }^{\circ} \mathrm{C}$ over a $40 \mathrm{~min}$ period. Our data show differential expression of genes involved in different cellular processes, including the SOS response, cell division and specific (heat) stress responses. For many differentially expressed genes, a transient expression pattern was observed between 3 and $40 \mathrm{~min}$ after temperature upshift. The highest number of differentially expressed genes was observed $3 \mathrm{~min}$ after temperature upshift. Whole-genome expression profiles in response to heat shock have been reported for B. subtilis, Shewanella oneidensis and Campylobacter jejuni (Gao et al., 2004; Helmann et al., 2001; Stintzi, 2003). These studies also showed transient expression patterns, albeit that peak numbers of differentially expressed genes were observed at later times after heat exposure. The ability of $L$. monocytogenes to rapidly alter transcript levels allows for a quick response to sudden environmental changes.

In L. monocytogenes, genes belonging to the class I and class III heat-shock regulons showed increased expression during heat exposure. Interestingly, the class I heat-shock genes showed a constant induction in expression levels over the 40 min period, whereas the class III heat-shock genes showed a transient expression pattern. This is likely related to the different roles that the two classes fulfil during heat shock. The Clp-ases are specifically required at the early stages of heat shock to remove the proteins initially damaged and misfolded. Following adaptation to heat, Clp-ase levels are reduced, while higher levels of chaperones are present to prevent accumulation of damaged and misfolded proteins. Q-PCR showed 1.5-fold induction of the gene encoding $\operatorname{SigB}$ after 3 and $10 \mathrm{~min}$. Considering the role of $\mathrm{SigB}$ as a regulator, this slight increase in expression appears to be enough to induce genes that contain a SigB promoter, as evidenced by the transient nature of the class II stress response. When present in B. subtilis, C. jejuni and S. oneidensis (Gao et al., 2004; Helmann et al., 2001; Stintzi, 2003), genes belonging to the class I and class III heat-shock response and SigB-regulated class II stress response were induced upon heat shock. Given the genetic resemblance and similar heat-shock conditions applied, a direct comparison of upregulated genes of L. monocytogenes and B. subtilis (Helmann et al., 2001) was possible. A total of 25 orthologues of the 130 induced class II stress genes in B. subtilis showed induction in L. monocytogenes as well. Of these 25 genes, eight had been previously identified in L. monocytogenes to be SigB-regulated (Kazmierczak et al., 2003). In $B$. subtilis, 76 other genes, designated class $\mathrm{U}$, show increased expression upon heat shock. In L. monocytogenes, nine orthologues of these genes showed induction, including htrA. Other research has shown that HtrA is important for survival during exposure to environmental and cellular stresses (Stack et al., 2005; Wilson et al., 2006).

In L. monocytogenes, several genes that play a role in the SOS response and DNA repair machinery showed increased expression after heat exposure, including $\operatorname{rec} A$, which is the major activator of the SOS response. RecA is involved in various processing steps of DNA replication proteins and repair proteins, and plays a role in the restart of stalled replication forks (Cox et al., 2000), homologous recombination, repair of double-stranded DNA breaks (Lusetti \& Cox, 2002) and introduction of adaptive point mutations (McKenzie et al., 2001). Furthermore, it stimulates cleavage of the LexA repressor of the SOS response, activating expression of the SOS response genes (Fig. 4). The LexA repressor is autoregulatory, and binds to the operator sequence in the promoter region of the SOS response genes (CGAACATATGTTCG in B. subtilis; Au et al., 2005). Several LexA-regulated genes showed increased expression in L. monocytogenes, including genes encoding the two alternative DNA polymerases $u m u D C$ and $\operatorname{din} B$. DNA polymerases Pol IV (DinB) and Pol V $\left(\mathrm{UmuD}_{2}{ }^{\prime} \mathrm{C}\right)$ have previously been shown to respond to inhibition of replication fork progression in a damage-independent manner (Godoy et al., 2006; Hare et al., 2006). Elevated temperatures may cause the L. monocytogenes DNA replication fork to stall, leading to exposure and possible degradation of the arrested replication fork without rescue by Pol IV and Pol V. This theory is consistent with the observation that heat shock resulted in cell elongation and prevention of cell division. This effect is called 'nucleoid occlusion' and is generally interpreted as prevention of Zring formation in the vicinity of the nucleoid, thereby preventing cell division without complete replication and segregation of the nucleoid (Rothfield et al., 2005). The expression profiles showed two mechanisms that might lead to the prevention of Z-ring formation after heat shock (Fig. 5). The first mechanism would be the result of increased expression of yneA (as part of the SOS response), which is responsible for suppression of cell division in $B$. subtilis by reducing the level of FtsZ proteins at the cell division site, thereby preventing FtsZ ring formation (Kawai et al., 2003). The second mechanism is the result of a decreased expression of minDE and $\operatorname{divIVA}$, which are involved in spatially correct septum placement. The MinCD complex negatively regulates formation of the cytokinetic Z-ring to midcell by preventing its formation near the poles (Zhou \& Lutkenhaus, 2005). Another strategy of L. monocytogenes to suppress cell division might be to decrease expression of $f t e X$ and $f t s E$. These encode proteins with sequence similarity to $\mathrm{ABC}$ transporters and 
(a)

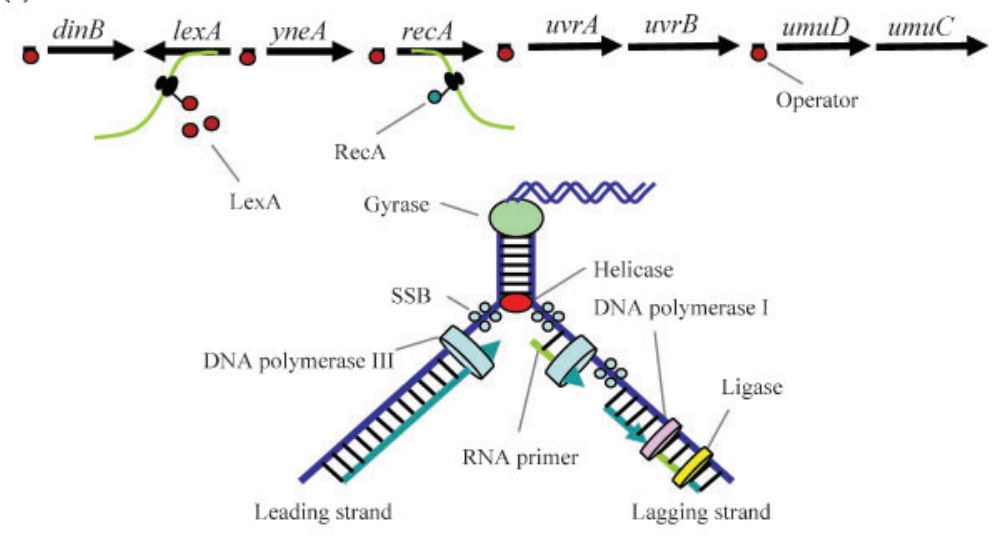

(b)

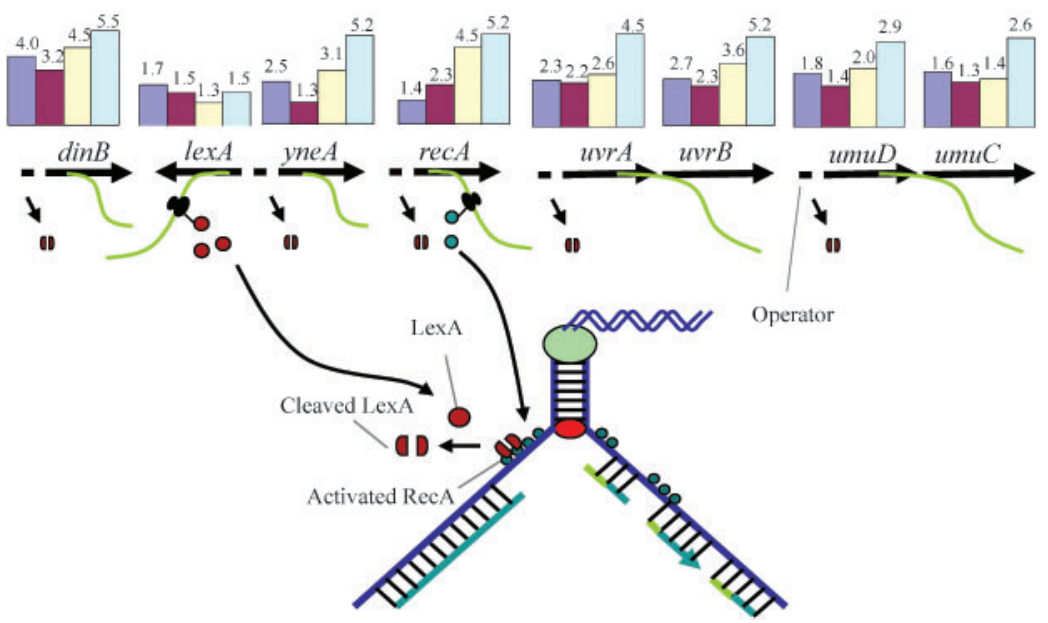

Fig. 4. Activation of the SOS response of $L$. monocytogenes during exposure to elevated temperatures. (a) In cells with an active replication fork (before exposure), LexA represses the transcription of $\operatorname{lex} A, \operatorname{rec} A$ and the other genes of the SOS response ( $\operatorname{din} B$, $y n e A, u v r A B$ and $u m u D C$ ) by binding to the operator in the promoter region. (b) When the replication fork is stalling after exposure to elevated temperatures, RecA is activated by the resulting ssDNA. Activated RecA promotes cleavage of LexA and consequently the SOS response genes are induced. The genes of the SOS response are illustrated schematically and are not to scale. The induction of the genes after heat shock is represented by the bar charts above each gene (blue, $3 \mathrm{~min}$; purple, $10 \mathrm{~min}$; yellow, $20 \mathrm{~min}$; green, $40 \mathrm{~min}$ ). are localized at the division site. In E. coli they are directly involved in cell division and are important for septal ring formation (Schmidt et al., 2004). Mutants for ftsXE constitutively showed induction of the SOS response in E. coli (O’Reilly \& Kreuzer, 2004).

A possible strategy for L. monocytogenes cells to prevent continuous elongation after suppression of cell division is to reduce the expression of genes that encode proteins involved in cell wall biosynthesis and turnover. The downregulated genes $\operatorname{rod} A$ and $m r e D C B$ encode proteins involved in cell wall synthesis and the determination of cell shape. The MreDCB complex forms actin-like cables beneath the cell surface and requires RodA for the control of cell shape (Kruse et al., 2005). Research in B. subtilis has shown that cells depleted of RodA are impaired in cell division (Henriques et al., 1998). Reduced expression levels were also observed for the genes encoding autolysins, for $\operatorname{murB}$, which is an essential gene in the biosynthetic pathway of peptidoglycan, and for the $d l t$ operon, which encodes products that catalyse the incorporation of $\mathrm{D}$ alanine residues into teichoic acids. While most bacteria show slower growth rates after mutations in the dlt operon, Streptococcus gordonii shows abnormal septation and defective cell separation (Neuhaus \& Baddiley, 2003).

PrfA and various other virulence genes showed induction upon heat exposure, which has apparently not been reported before. PrfA is the major virulence regulator in L. monocytogenes (Chakraborty et al., 1992; LeimeisterWachter et al., 1990). Previous studies have shown maximal induction of the virulence genes at $37{ }^{\circ} \mathrm{C}$ (Johansson et al., 2002; Leimeister-Wachter et al., 1992). However, expression levels at temperatures above $37{ }^{\circ} \mathrm{C}$ were not measured in these studies. Destabilizing mutations in the secondary structure of the untranslated region of prfA mRNA resulted in increased levels of PrfA at $37{ }^{\circ} \mathrm{C}$ (Johansson et al., 2002), indicating that this structure is not completely unfolded at this temperature. Increasing the temperature above $37{ }^{\circ} \mathrm{C}$ probably results in a more relaxed secondary structure, allowing more PrfA translation.

A comparative analysis of the transcription profiles of $L$. monocytogenes during heat shock and in the intracellular 


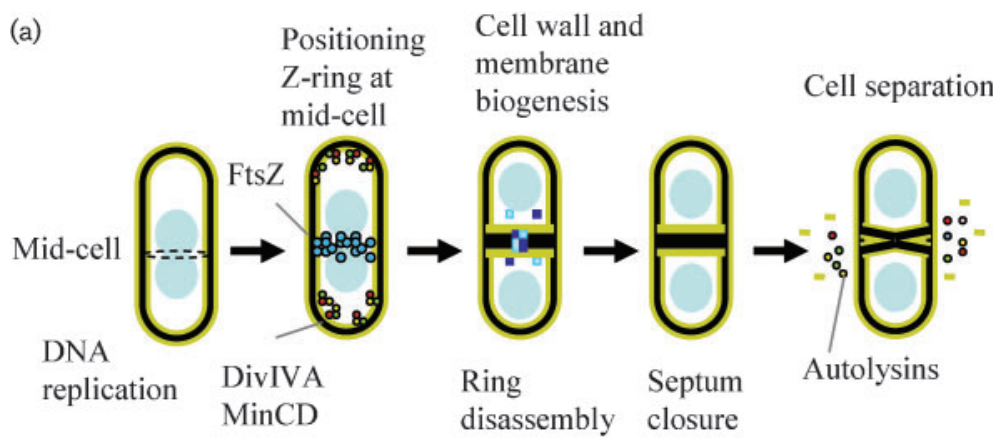

(b)

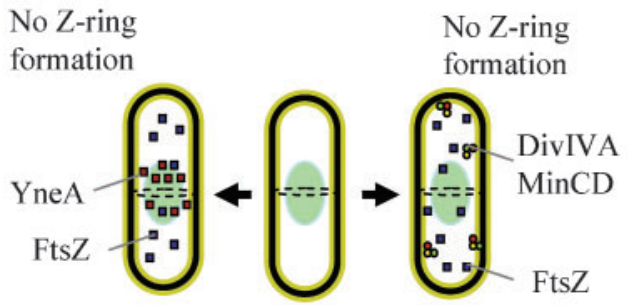

Stalled DNA

replication
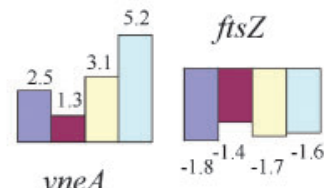

yneA
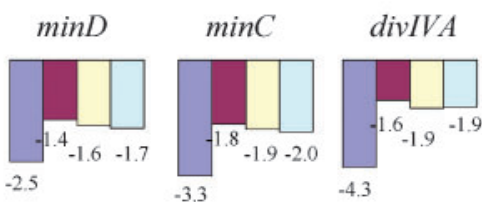

environment (Chatterjee et al., 2006) showed a high number of genes that were differentially expressed during both exposures. Of the 714 genes differentially expressed during heat shock, 236 showed differential expression in the intracellular environment as well. Among genes that were commonly regulated during both exposures, 172 showed increased expression and 64 showed decreased expression. Exposure of L. monocytogenes to the intracellular environment triggered numerous (heat) stressresponse genes that were shown to be differentially expressed during heat shock in this study. All genes belonging to the class I and class III heat-shock-response classes and 24 of the SigB-regulated class II stress-response genes showed induction in the intracellular environment. Remarkably, similar expression profiles for SOS response genes, cell division genes and cell-wall-related genes were observed. This comparative analysis showed that numerous responses induced during heat exposure contribute to the pathogenicity of L. monocytogenes by allowing survival under the stressful conditions encountered intracellularly and during passage through the stomach and the intestinal tract.

This study shows the importance of the SOS response as a common protection mechanism during heat shock, and its possible role in suppression of cell division to prevent transection of the genome as a result of incomplete chromosomal segregation. Whether replication fork stalling is the actual cause that leads to both the SOS response and suppression of cell division remains to be elucidated. This opens up interesting possibilities for future research. Our transcriptome analysis has revealed several aspects of the heat-shock response of $L$. monocytogenes that may include targets for inactivation. The role of specific factors, such as the SOS response in L. monocytogenes stress survival and virulence, will be assessed in future studies.

\section{ACKNOWLEDGEMENTS}

We thank Alexandra Amend-Förster for her excellent technical assistance. We thank Carsten T. Künne and Andre Billion for providing helpful analysis programs for microarray data. Support for this work was provided by funds from the ERA-NET Pathogenomics Network supported by the Bundesministerium für Bildung und Forschung (BMBF) and from the Sonderforschungsbereich 535 supported by the Deutsche Forschungsgemeinschaft to T. C. and T. H.

\section{REFERENCES}

Au, N., Kuester-Schoeck, E., Mandava, V., Bothwell, L. E., Canny, S. P., Chachu, K., Colavito, S. A., Fuller, S. N., Groban, E. S. \& other authors (2005). Genetic composition of the Bacillus subtilis SOS system. J Bacteriol 187, 7655-7666.

Autret, N., Raynaud, C., Dubail, I., Berche, P. \& Charbit, A. (2003). Identification of the agr locus of Listeria monocytogenes: role in bacterial virulence. Infect Immun 71, 4463-4471. 
Benson, A. K. \& Haldenwang, W. G. (1993). The $\sigma^{\mathrm{B}}$-dependent promoter of the Bacillus subtilis sigB operon is induced by heat shock. J Bacteriol 175, 1929-1935.

Caldas, T., Demont-Caulet, N., Ghazi, A. \& Richarme, G. (1999). Thermoprotection by glycine betaine and choline. Microbiology 145, 2543-2548.

Chakraborty, T., Leimeister-Wachter, M., Domann, E., Hartl, M., Goebel, W., Nichterlein, T. \& Notermans, S. (1992). Coordinate regulation of virulence genes in Listeria monocytogenes requires the product of the prfA gene. J Bacteriol 174, 568-574.

Chatterjee, S. S., Hossain, H., Otten, S., Kuenne, C., Kuchmina, K., Machata, S., Domann, E., Chakraborty, T. \& Hain, T. (2006). Intracellular gene expression profile of Listeria monocytogenes. Infect Immun 74, 1323-1338.

Cox, M. M., Goodman, M. F., Kreuzer, K. N., Sherratt, D. J., Sandler, S. J. \& Marians, K. J. (2000). The importance of repairing stalled replication forks. Nature 404, 37-41.

Doorduyn, Y., de Jager, C. M., van der Zwaluw, W. K., Wannet, W. J., van der Ende, A., Spanjaard, L. \& van Duynhoven, Y. T. (2006). First results of the active surveillance of Listeria monocytogenes infections in the Netherlands reveal higher than expected incidence. Euro Surveill 11, E060420-E060424.

Gao, H., Wang, Y., Liu, X., Yan, T., Wu, L., Alm, E., Arkin, A., Thompson, D. K. \& Zhou, J. (2004). Global transcriptome analysis of the heat shock response of Shewanella oneidensis. J Bacteriol 186, 7796-7803.

Glaser, P., Frangeul, L., Buchrieser, C., Rusniok, C., Amend, A., Baquero, F., Berche, P., Bloecker, H., Brandt, P. \& other authors (2001). Comparative genomics of Listeria species. Science 294, 849-852.

Godoy, V. G., Jarosz, D. F., Walker, F. L., Simmons, L. A. \& Walker, G. C. (2006). Y-family DNA polymerases respond to DNA damageindependent inhibition of replication fork progression. EMBO J $\mathbf{2 5}$, 868-879.

Hare, J. M., Perkins, S. N. \& Gregg-Jolly, L. A. (2006). A constitutively expressed, truncated $u m u D C$ operon regulates the recA-dependent DNA damage induction of a gene in Acinetobacter baylyi strain ADP1. Appl Environ Microbiol 72, 4036-4043.

Health Protection Agency (2005). The changing epidemiology of listeriosis in England and Wales. Commun Dis Rep CDR Wkly 15, (38)3-4.

Helmann, J. D., Wu, M. F., Kobel, P. A., Gamo, F. J., Wilson, M., Morshedi, M. M., Navre, M. \& Paddon, C. (2001). Global transcriptional response of Bacillus subtilis to heat shock. J Bacteriol 183, 7318-7328.

Henriques, A. O., Glaser, P., Piggot, P. J. \& Moran, C. P., Jr (1998). Control of cell shape and elongation by the rodA gene in Bacillus subtilis. Mol Microbiol 28, 235-247.

Holtmann, G. \& Bremer, E. (2004). Thermoprotection of Bacillus subtilis by exogenously provided glycine betaine and structurally related compatible solutes: involvement of Opu transporters. J Bacteriol 186, 1683-1693.

Johansson, J., Mandin, P., Renzoni, A., Chiaruttini, C., Springer, M. \& Cossart, P. (2002). An RNA thermosensor controls expression of virulence genes in Listeria monocytogenes. Cell 110, 551-561.

Kallipolitis, B. H. \& Ingmer, H. (2001). Listeria monocytogenes response regulators important for stress tolerance and pathogenesis. FEMS Microbiol Lett 204, 111-115.

Karatzas, K. A., Valdramidis, V. P. \& Wells-Bennik, M. H. (2005). Contingency locus in ctsR of Listeria monocytogenes Scott A: a strategy for occurrence of abundant piezotolerant isolates within clonal populations. Appl Environ Microbiol 71, 8390-8396.
Kawai, Y., Moriya, S. \& Ogasawara, N. (2003). Identification of a protein, YneA, responsible for cell division suppression during the SOS response in Bacillus subtilis. Mol Microbiol 47, 1113-1122.

Kazmierczak, M. J., Mithoe, S. C., Boor, K. J. \& Wiedmann, M. (2003). Listeria monocytogenes $\sigma^{\mathrm{B}}$ regulates stress response and virulence functions. J Bacteriol 185, 5722-5734.

Koch, J. \& Stark, K. (2006). Significant increase of listeriosis in Germany - epidemiological patterns 2001-2005. Euro Surveill 11, 85-88.

Komatsuzawa, H., Fujiwara, T., Nishi, H., Yamada, S., Ohara, M., McCallum, N., Berger-Bachi, B. \& Sugai, M. (2004). The gate controlling cell wall synthesis in Staphylococcus aureus. Mol Microbiol 53, 1221-1231.

Kruger, E. \& Hecker, M. (1998). The first gene of the Bacillus subtilis $c l p C$ operon, $c t s R$, encodes a negative regulator of its own operon and other class III heat shock genes. J Bacteriol 180, 6681-6688.

Kruse, T., Bork-Jensen, J. \& Gerdes, K. (2005). The morphogenetic MreBCD proteins of Escherichia coli form an essential membranebound complex. Mol Microbiol 55, 78-89.

Leimeister-Wachter, M., Haffner, C., Domann, E., Goebel, W. \& Chakraborty, T. (1990). Identification of a gene that positively regulates expression of listeriolysin, the major virulence factor of Listeria monocytogenes. Proc Natl Acad Sci U S A 87, 8336-8340.

Leimeister-Wachter, M., Domann, E. \& Chakraborty, T. (1992). The expression of virulence genes in Listeria monocytogenes is thermoregulated. J Bacteriol 174, 947-952.

Lusetti, S. L. \& Cox, M. M. (2002). The bacterial RecA protein and the recombinational DNA repair of stalled replication forks. Annu Rev Biochem 71, 71-100.

Maul, R. W. \& Sutton, M. D. (2005). Roles of the Escherichia coli RecA protein and the global SOS response in effecting DNA polymerase selection in vivo. J Bacteriol 187, 7607-7618.

McKenzie, G. J., Lee, P. L., Lombardo, M. J., Hastings, P. J. \& Rosenberg, S. M. (2001). SOS mutator DNA polymerase IV functions in adaptive mutation and not adaptive amplification. Mol Cell 7, 571-579.

Michel, B. (2005). After 30 years of study, the bacterial SOS response still surprises us. PLoS Biol 3, e255.

Miller, C., Thomsen, L. E., Gaggero, C., Mosseri, R., Ingmer, H. \& Cohen, S. N. (2004). SOS response induction by $\beta$-lactams and bacterial defense against antibiotic lethality. Science 305, 1629-1631.

Milohanic, E., Glaser, P., Coppee, J. Y., Frangeul, L., Vega, Y., Vazquez-Boland, J. A., Kunst, F., Cossart, P. \& Buchrieser, C. (2003). Transcriptome analysis of Listeria monocytogenes identifies three groups of genes differently regulated by PrfA. Mol Microbiol 47, 1613-1625.

Neuhaus, F. C. \& Baddiley, J. (2003). A continuum of anionic charge: structures and functions of D-alanyl-teichoic acids in Gram-positive bacteria. Microbiol Mol Biol Rev 67, 686-723.

O'Reilly, E. K. \& Kreuzer, K. N. (2004). Isolation of SOS constitutive mutants of Escherichia coli. J Bacteriol 186, 7149-7160.

Rauch, M., Luo, Q., Muller-Altrock, S. \& Goebel, W. (2005). SigBdependent in vitro transcription of prfA and some newly identified genes of Listeria monocytogenes whose expression is affected by PrfA in vivo. $J$ Bacteriol 187, 800-804.

Rothfield, L., Taghbalout, A. \& Shih, Y. L. (2005). Spatial control of bacterial division-site placement. Nat Rev Microbiol 3, 959-968.

Schmidt, K. L., Peterson, N. D., Kustusch, R. J., Wissel, M. C., Graham, B., Phillips, G. J. \& Weiss, D. S. (2004). A predicted ABC transporter, FtsEX, is needed for cell division in Escherichia coli. J Bacteriol 186, 785-793.

Schulz, A. \& Schumann, W. (1996). hrcA, the first gene of the Bacillus subtilis dnaK operon encodes a negative regulator of class I heat shock genes. J Bacteriol 178, 1088-1093. 
Sleator, R. D., Wouters, J., Gahan, C. G., Abee, T. \& Hill, C. (2001). Analysis of the role of OpuC, an osmolyte transport system, in salt tolerance and virulence potential of Listeria monocytogenes. Appl Environ Microbiol 67, 2692-2698.

Stack, H. M., Sleator, R. D., Bowers, M., Hill, C. \& Gahan, C. G. (2005). Role for HtrA in stress induction and virulence potential in Listeria monocytogenes. Appl Environ Microbiol 71, 4241-4247.

Stintzi, A. (2003). Gene expression profile of Campylobacter jejuni in response to growth temperature variation. J Bacteriol 185, 2009-2016.

Wemekamp-Kamphuis, H. H., Sleator, R. D., Wouters, J. A., Hill, C. \& Abee, T. (2004). Molecular and physiological analysis of the role of osmolyte transporters BetL, Gbu, and OpuC in growth of
Listeria monocytogenes at low temperatures. Appl Environ Microbiol 70, 2912-2918.

Wilson, R. L., Brown, L. L., Kirkwood-Watts, D., Warren, T. K., Lund, S. A., King, D. S., Jones, K. F. \& Hruby, D. E. (2006). Listeria monocytogenes $10403 \mathrm{~S} \mathrm{HtrA}$ is necessary for resistance to cellular stress and virulence. Infect Immun 74, 765-768.

Zhou, H. \& Lutkenhaus, J. (2005). MinC mutants deficient in MinDand DicB-mediated cell division inhibition due to loss of interaction with MinD, DicB, or a septal component. J Bacteriol 187, 2846-2857.

Edited by: J. Lindsay 